\title{
Captain Norton's Percussion Grenade for House Defence
}

\section{Captain Norton}

To cite this article: Captain Norton (1866) Captain Norton's Percussion Grenade for House Defence, Royal United Services Institution. Journal, 10:40, 289-290, DOI: 10.1080/03071846609417202

To link to this article: http://dx.doi.org/10.1080/03071846609417202

册 Published online: 11 Sep 2009.

Submit your article to this journal $\sqsubset \pi$

Џ Article views: 2

Q View related articles $₫$ 


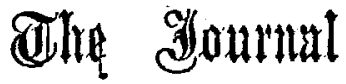

\section{OF TIIS

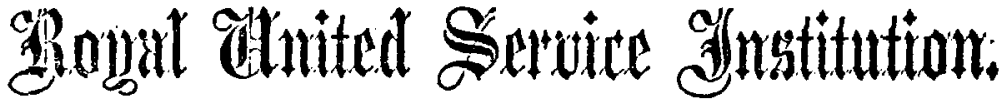

$\begin{array}{lll}\text { You. X. } & 1866 . & \text { No. XL. }\end{array}$

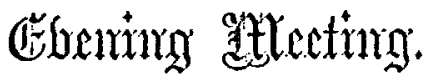

Monday, April 9th, 1866.

Gaptadx E. GARDINER FISHBOURNE, R.N., C.B., in the Chair.

FAMES of ALEMCBERS who joined the Institution between the 19th Mrarch and the 9th April, 1866.

ANTUAL.

Brooker, G. A. C., Capt., R.N. 11. Pryce, J., Capt. lato Glamorganshire Mil. Graham, O.,Licut.H.MI. MIad. Staff Corps. Barringtom, J. T., Roy. Artillery. 1 l. $1 l$.

The Crimmax: Captain Norton, who I suppose was almost the first person, at least if not the first, one of the earliest persons to draw attention to the subject of rifles and the use of rifled shot, has. sent for the Misseum and exhibition, a percussion hand grenade for house defence. He shows his great ingenuity in all such matters. He had the misfortune to be born some fifty years before his time. Had it not been so he would hare been a very great man.

Cartaix Norton's Percussiox Grexade for Itodse Defence.

(Dedicated, by permission, to General Sir IIugh Rose, G.C.B., Commander of the Forces in Ireland.)

The fuze grenade is not good for house defence, because when the fuze is lighted the grenade must be thrown, or got rid of, as it would rot. $x$, 
otherwise burst in the hand and destroy the person. My percussion grenade has no fuze to be lighted, and

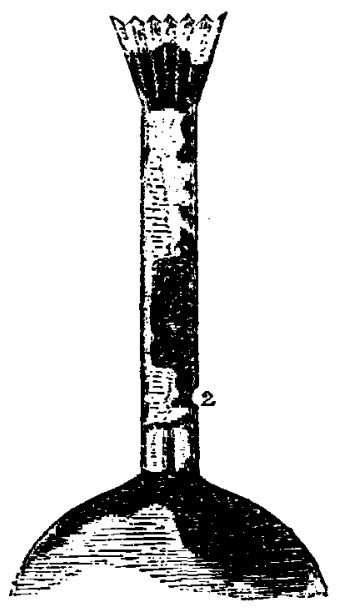

1. Ieaden bolt for pulverizing glass tube.

2. Iroln for inserting glass tube holder.

of falling on the ground explodes the grenade.

Annexed is a drawing of the winged tube containing the glass tube igniter, and which is screwed into the iron grenade** can be thrown at any time. $\Lambda$ daring assailant could pick up the fuze grenade and throw it back; my grenado could not bo thrown back with effect. The gronade can be made to fire with a percussion cap if so required. In using revolvers for house defence, the person is necessarily exposed to the fire of tho assailants, but in using percussion grenades, the person need not be exposed, as the grenade may be allowed to slido through a temporary spout downwards and outwards.

\section{Directions for Use.}

When the grenade is abont to be used, the winged tube is held slanting down wards so that the leaden bolt within it slides back and leares the touch-hole open for the insertion of the glass tube igniter; then holding the winged tube perpendicular, the leaden bolt rests upon the glass tube igniter, and on the grenade being thrown out of a window, the shock pulverizes the glass tube and fires and

\section{ON PROJECTILES.}

\section{By Mrchatel Scotr, Esq., C.E.}

With the permission of the meeting the author proposes on the present occasion to confine his observations mainly to a class of projectiles which may be said to occupy an intermediate place between spherical shot and elongated rifle bolts.

In the year 1862 the writer published a pamphletf in which he explained a principle whereby the want of homogencity in elongated projectiles might be obviated, and in which he stated that the centre of gravity being corrected, and the projectile made symmetrical, it would not deviate from the true line of flight, eren although not rotating upon its axis.

* They can bo obtained at Mr. Calderwood's, Gunmaker, Sackvillo Strect, Dublin.

t On Projectiles and Guns. By Michael Scott, C.E. Clowes and Son, Charing Cross. 